\title{
A re-investigation on the identity of Litsea nigrescens (Lauraceae) in the Western Ghats of India
}

\author{
Robi A.J. ${ }^{1^{*}}$ \& P.S. Udayan ${ }^{2}$ \\ 'Department of Botany, Bishop Abraham Memorial College, Thuruthicad, Pathanamthitta, Kerala - 689 597, India. \\ 2Post Graduate Department of Botany \& Research Centre, Sree Krishna College, Guruvayur, Kerala - 680 102, India. \\ *E-mail: ajrobin80@gmail.com
}

\begin{abstract}
Litsea nigrescens Gamble has been considered as endangered in the wild. Hitherto, there are no records of this species from the Western Ghats, India after the type collection. Recently, its presence in the Western Ghats was confirmed. It was long confused with $L$. oleoides (Meisn.) Hook.f., a rare species distributed only in the shola forests of Nilgiris and Pulneys. A detailed description, photographs, distribution, ecology and taxonomic history are provided.
\end{abstract}

Keywords: Kerala, Lauraceae, Nilgiris, Rediscovery, Shola forest.

\section{Introduction}

Litsea Lam. (Lauraceae) consists of more than 400 species, chiefly distributed in tropical Asia, with a few species in the Pacific islands, Australia, and in North and Central America (Werff, 2001). More than 46 taxa of this genus are reported from India, predominantly concentrated in northeastern India and southern India (Bhuinya et al., 2009; Robi, 2014; Robi et al., 2015). Of these, 22 species are recorded from South India (Robi \& Udayan, 2013; Robi, 2014). Litsea is distinct from other genera in Lauraceae by their umbellate inflorescences, unisexual trimerous flowers, nine stamens, 4-locular anthers, equal or reduced tepals, small to rather large one-seeded berries seated on a cup-shaped perianth tube, and alternate or sometimes opposite or rarely whorled leaves, which in some species are crowded towards the apex.

While revising the species of Litsea in the Western Ghats, inconsistencies were noticed in the

Received: 19.05.2020; Revised \& Accepted: 12.09.2020

Published Online: 31.12.2020 identification of L. nigrescens Gamble and L. oleoides (Meisn.) Hook.f. An extensive study of the literature (Ramachandran \& Nair, 1988; Vajravelu, 1990; Sasidharan \& Sivarajan, 1996; Mohanan \& Sivadasan, 2002), herbarium specimens housed at CES, CAL, CALI, K, KFRI, MH, RHT and live material, enabled us to correctly distinguish these two taxa, and recognize them as distinct. Further studies on the specimens revealed that the majority of L. nigrescens collections have been mistakenly identified as L. oleoides, an allied species rarely distributed in shola forests of Nilgiris and Pulney hills. The present paper provides a detailed description and taxonomic affinities of $L$. nigrescens along with other relevant notes, and color photographs to facilitate easy differentiation and identification of the species.

\section{Taxonomic treatment}

Litsea nigrescens Gamble, Fl. Pres. Madras 2: 1236. 1925; V.Chandras. in A.N.Henry et al., Fl. Tamil Nadu 2: 211. 1987; Sasidh., Biodiv. Doc. Kerala-Fl. Pl. 399. 2004; Bhuinya et al., Bangladesh J. Pl. Taxon. 17(2): 187. 2010. Lectotype (designated by Singh, 2015): INDIA, Kerala, Travancore hills, 1889, T.F. Bourdillon 48 (K [K000357614 digital image!]).

Tetranthera panamanja auct. Wight, Icon. Pl. Ind. Orient. 5: t. 1836. 1852, non Buch.-Ham., 1830.

Litsea oleoides auct. non (Meisn.) Hook.f.: V.S.Ramach. \& V.J.Nair, Fl. Cannanore Dist. 397. 1988; Vajr., Fl. Palghat Dist. 405. 1990; M.Mohanan \& A.N.Henry, Fl. Thiruvananthapuram 395. 1994; 
Sasidh. \& Sivar., Fl. Pl. Thrissur For. 383. 1996; Sasidh., Fl. Shenduruny WLS 273. 1997; Sivar. \& P.Mathew, Fl. Nilambur 587. 1997; Sasidh., Fl. Parambikulam WLS 270. 2002; N.Mohanan \& Sivad., Fl. Agasthyamala 571. 2002; Anil Kumar et al., Fl. Pathanamthitta 425. 2005.

Fig. 1

Trees, to $20 \mathrm{~m}$ tall; bark pale brown, smooth, slightly rugose, yellowish-brown inside; branchlets greyish, glabrous, stout. Leaves simple, alternate, estipulate; petioles 10-30 mm long, stout, grooved above, glabrous; lamina 6-22 × 7-12 cm, oblong, elliptic-oblong or elliptic-lanceolate, base attenuate to cuneate, apex acuminate or acute, margins entire, glabrous, pale-brown or black beneath when dry, thinly coriaceous; midrib glabrous on both sides, slightly grooved above, prominent beneath; lateral veins $10-12$ pairs, pinnate, arcuate, immersed above, obscure beneath, intercostae reticulate obscure. Inflorescences umbels, on reduced branchlets (brachyblasts) with the appearance of a raceme of umbels, axillary; brachyblast c. $6 \mathrm{~cm}$ long, bearing 5-8 umbels; peduncles $6 \mathrm{~mm}$ long; involucral bracts 4 , orbicular, c. $5 \times 3 \mathrm{~mm}$, concave, densely silky pubescent, coriaceous. Flowers unisexual, 3-6 in each umbel, white, $4 \mathrm{~mm}$ long, silky-pubescent; tepals 6, lanceolate or oblong, c. 3 $\times 1.5 \mathrm{~mm}$, acute, subequal, membranaceous, glabrous inside, silky-pubescent outside, creamywhite; pedicels c. $3 \mathrm{~mm}$ long, densely silky pubescent. Male flowers: Stamens 12, in 4 rows, unequal; filaments slender, villous, all with 2-glands at the base, c. $3 \mathrm{~mm}$ long in outer stamens, c. $2 \mathrm{~mm}$ long in inner stamens; anthers c. $1.5 \mathrm{~mm}$ long, 4locular, the upper 2 smaller, lower 2 larger, introrse; pistillodes minute or rudimentary. Female flowers: Staminodes as many as stamens in male, outer ones linear, inner ones subulate, 2-3 mm long, 2glandular at the base; ovary globose, c. $1 \mathrm{~mm}$ long; style c. $1 \mathrm{~mm}$ long, thick; stigma capitate, papillose. Berries depressed globose, 2-2.5 cm across, greenish, reddish to dark purple, white specked, smooth, glossy, seated on a perianth tube; perianth tube disc-shaped, persistent, $1 \mathrm{~cm}$ across, glabrous outside, margins entire; fruiting pedicels stout, angular, c. $7 \mathrm{~mm}$ long.
Flowering \& fruiting: Flowering from September to December and fruiting from December to May.

Habitat: Growing in evergreen forests between 800-1400 m above sea level.

\section{Distribution: Endemic to South India.}

Specimens examined: INDIA, Karnataka, Coorg district, Bhagamandala to Thadiyandamol, 12.05.2010, P.S. Udayan, A.J. Robi E Satheesh George 6801 (CMPR). Kerala, Idukki district, Kumily, Patham mile, 16.06.1976, C.D. Ridsdale $152(\mathrm{MH})$; Malappuram district, Thalichola, 05.02.1982, Philip Mathew 33098 (CALI); Palakkad district, Nelliampathy, \pm 800 m, 31.05.2008, P.S. Udayan, Satheesh George \& K.V. Thushar 5091 (CMPR); Thrissur district, Sholayar, \pm 700 m, 12.08.1981, N.G. Nair 49 (KFRI). Tamil Nadu, Namakkal district, Kodai, Thdiankudisai, $\pm 1050 \mathrm{~m}$, 13.04.1987, K.M. Matthew 49272 (RHT); ibid., \pm 1100 m, 14.04.1987, K.M. Matthew 49285 (RHT); Madal shola, \pm 1225 m, 17.04.1977, D.I. Arockia Sammy 7694 (RHT); Periya shola, $\pm 1300 \mathrm{~m}$, 16.10.1977, K.M. Matthew \& V. Karunichhi 9707 (RHT); ibid., \pm 1325 m, 21.10.1978, K.M. Matthew E C. Manoharan 18668 (RHT); Pongal shola, Kolli hills, \pm 1200 m, 14.04.1997, D.I. Arockia Sammy 7577 (RHT).

Notes: Meisner (1864) described Tetranthera oleoides Meisn. based on the specimens collected from Sispara, Nilgiri hills by Robert Wight in 1840. Subsequently, the transfer of T. oleoides into Litsea and its first combination, Litsea oleoides (Meisn.) Hook.f. was made by Hooker (1886) in the Flora of British India. He also commented that "Meisner describes this as having opposite or sub-opposite leaves, but I find them opposite only on very young shoots".

T.F. Bourdillon, collected a specimen of Litsea (T.F. Bourdillon 48, K) from the Travancore hills in 1889 and doubtfully annotated on the sheet "Litsea sp. n.? or aff. L. oleoides". D. Brandis in 1904 attached a determinavit on the sheet which read "L. oleoides has shining, rigidly coriaceous leaves with a very prominent midrib. They are opposite or nearly so, 

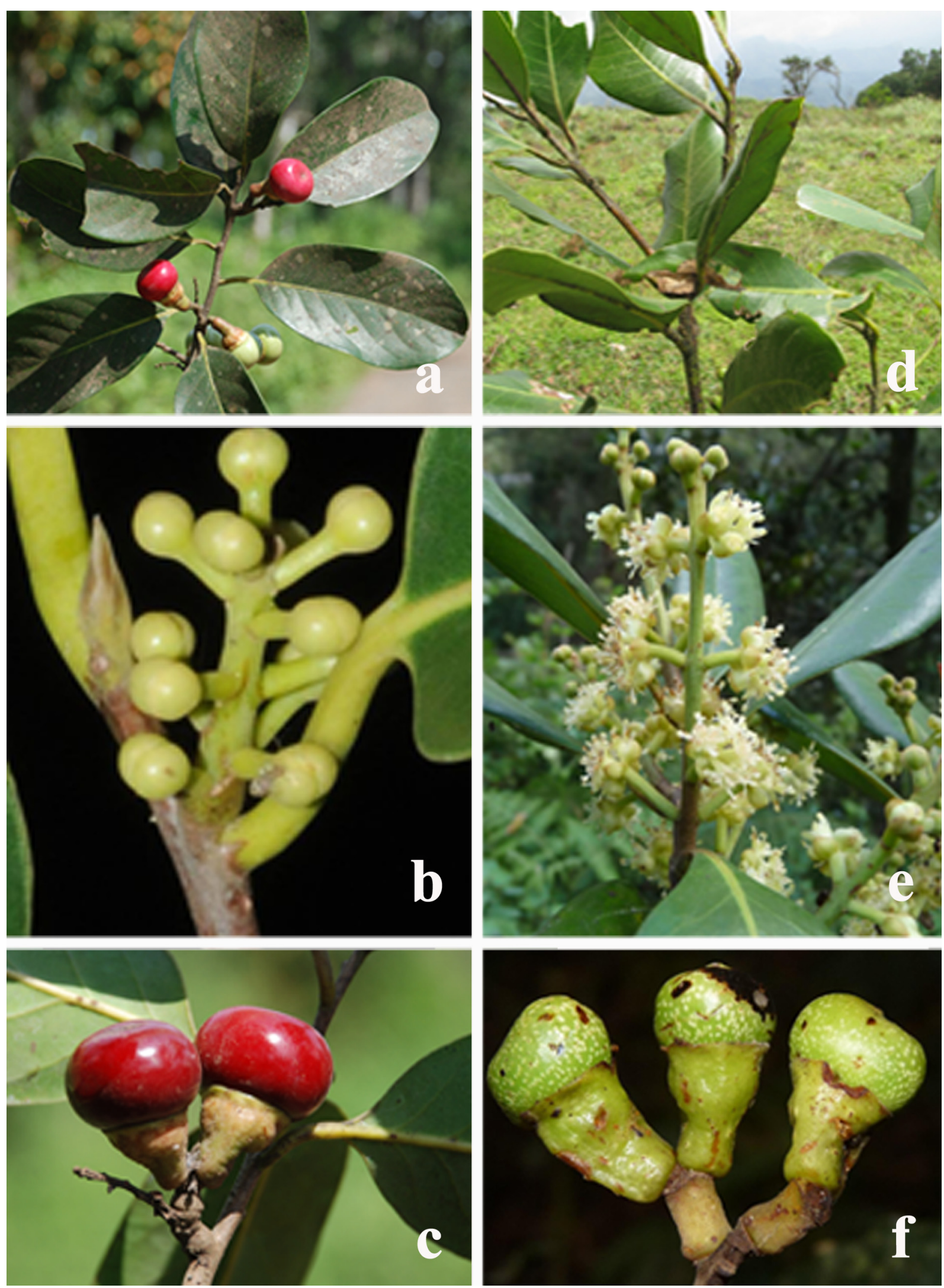

Fig. 1. a-c. Litsea nigrescens Gamble: a. Fruiting branch; b. Female brachyblast with unopened umbels; c. Ripe fruits; d-f. Litsea oleoides (Meisn.) Hook.f. d. Branch; e. Male brachyblast with opened umbels; f. Unripe fruits (photos a-c by A.J. Robi; d by K.A. Anilkumar \& e-f by R.K. Singh). 
Table 1. Comparison of morphological characters of L. nigrescens and L. oleoides

\begin{tabular}{|c|c|c|}
\hline Characters & L. nigrescens Gamble & L. oleoides (Meisn.) Hook.f. \\
\hline Branchlets & Terete, lenticellate & Angular, smooth \\
\hline Phyllotaxy & Alternate & Opposite or subopposite \\
\hline Lamina & $\begin{array}{l}6-22 \times 7-12 \mathrm{~cm}, \text { base attenuate to cuneate, } \\
\text { apex acuminate or acute, margins entire, } \\
\text { pale-brown or black beneath when dry, } \\
\text { thinly coriaceous }\end{array}$ & $\begin{array}{l}6-14 \times 3-5 \mathrm{~cm} \text {, base acute or rounded, apex acute } \\
\text { or obtuse or rounded, margins slightly incurved, } \\
\text { reddish-brown beneath when dry, rigidly } \\
\text { coriaceous }\end{array}$ \\
\hline Lateral veins & $10-12$ pairs & $8-10$ pairs \\
\hline Brachyblasts & $\begin{array}{l}\text { Terete, umbels arranged oppositely; } \\
\text { peduncles to } 6 \mathrm{~mm} \text { long }\end{array}$ & $\begin{array}{l}\text { Quadrangular, umbels arranged alternately; } \\
\text { peduncles to } 10 \mathrm{~mm} \text { long }\end{array}$ \\
\hline $\begin{array}{l}\text { Involucral } \\
\text { bracts }\end{array}$ & 4 & 6 \\
\hline Flowers & $3-6$ in each umbel & 4 in each umbel \\
\hline Staminodes & 12 & 9 \\
\hline Berries & $\begin{array}{l}2-2.5 \mathrm{~cm} \text { across, cup broadly obconic; } \\
\text { fruiting pedicels angular }\end{array}$ & $\begin{array}{l}1.5-2 \mathrm{~cm} \text { across, cup narrowly obconic; } \\
\text { fruiting pedicels terete }\end{array}$ \\
\hline
\end{tabular}

the novelty of Bourdillon's specimen and named it Litsea nigrescens in the Flora of Presidency of Madras. Litsea nigrescens resembles L. oleoides (Fig. 1) in its large, compressed globose and reddish fruits. The confusion due to the similarity between the fruits has lead to the misidentification of L. nigrescens as L. oleoides by several workers. However, Litsea nigrescens can be easily distinguished from $L$. oleoides in having thinly coriaceous, alternate leaves, 6-22 $\times$ 7-12 cm; 10-12 lateral veins; 3-6-flowered umbels and 12 staminodes per flower (Table 1). The present study reveals that the distribution of $L$. nigrescens is common in the wet evergreen forests of South India.

\section{Acknowledgements}

The authors are grateful to the curators of CAL, CALI, CES, K, KFRI, MH and RHT; the Department of Science \& Technology (DST), Government of India, New Delhi for the financial support: Mr. Rajeev Kumar Singh, BSI, Coimbatore and Dr. K.A. Anilkumar, Spices Board, Cochin for providing images. The support provided by staff from the Kerala Forest Department during the field work is thankfully acknowledged.

\section{Literature Cited}

BHUINYA T., SINGH P. \& S.K. MUKHERJEE 2009. Distribution of the genus Litsea Lam. (Lauraceae) in India with special reference to rare and endemic species. Phytotaxonomy 9: 116-121.

GAMBLE J.S. 1925. Flora of the Presidency of Madras. Volume 2(7). Adlard \& Sons Ltd., London.

HOOKER J.D. 1886. Laurineae. In: HOOKER J.D. (ed.), The flora of British India. Volume 5. L. Reeve \& Co., London. pp. 116-188.

MEISNER C.F. 1864. Lauraceae. In: CANDOLLE A.L.P.P. DE (ed.), Prodromus Systematis Naturalis Regni Vegetabilis. Volume 15(2). Fortin, Masson \& Co., Paris. pp. 1-260.

MOHANAN N. \& M. SIVADASAN 2002. Flora of Agasthyamala. Bishen Singh Mahendra Pal Singh, Dehradun.

RAMACHANDRAN V.S. \& V.J. NAIR 1988. Flora of Cannanore. Botanical Survey of India, Kolkata.

ROBI A.J. 2014. A taxonomic revision of the family Lauraceae from South India. Ph.D. Thesis (Unpublished), University of Kannur.

ROBI A.J. \& P.S. UDAYAN 2013. Taxonomic studies of the genus Litsea Lam. (Lauraceae) in Kerala. In: KISHORE K.K., BALAKRISHNAN P., RAJESH M.G. \& P. BALAKRISHNAN (eds.), Proceedings of the UGC National Seminar on Western Ghats Biogeography, Biodiversity \& Conservation. N.S.S. College, Manjeri. pp. 256-263. 
ROBI A.J., GEORGE S. \& K.V. THUSHAR 2015. Litsea udayanii (Lauraceae): a new species from the southern Western Ghats, India. Phytotaxa 222(1): 44-50. http:// dx.doi.org/10.11646/phytotaxa.222.1.4

SASIDHARAN N. \& V.V. SIVARAJAN 1996. Flowering plants of Thrissur forests. Scientific Publishers, Jodhpur.

SINGH R.K. 2015. Typification of seven species of Litsea
(Lauraceae) endemic to India. Phytotaxa 201(4): 278286. http://dx.doi.org/10.11646/phytotaxa.201.4.3

VAJRAVELU E. 1990. Flora of Palaghat district including Silent Valley National Park, Kerala. Botanical Survey of India, Kolkata.

WERFF H. 2001. An annotated key to the genera of Lauraceae in the flora Malesiana region. Blumea 46: 125-140. 